De Jure: Jurnal Hukum dan Syar'iah

Vol. 12, No. 2, 2020, h. 241-254

ISSN (Print): 2085-1618, ISSN (Online): 2528-1658

DOI: http://dx.doi.org/10.18860/j-fsh.v12i2.10072

Available online at http://ejournal.uin-malang.ac.id/index.php/syariah

\title{
Kesadaran Hukum Masyarakat dalam Implementasi Kebijakan Asuransi Nelayan di Kabupaten Bulukumba The Community Legal Awareness in Implementing Fishermen's Insurance Policies in Bulukumba Regency
}

\author{
Nurul Khasanah Dahlan \\ Universitas Hasanuddin Makassar, Indonesia \\ nurulkhasanahdahlan3@gmail.com \\ Farida Patitting \\ Universitas Hasanuddin Makassar, Indonesia \\ Kahar Lahae \\ Universitas Hasanuddin Makassar, Indonesia
}

\begin{abstract}
:
Fishermen are one of the high risk occupations. The protection of this work sometimes escapes the government's attention. This study aims to describe the application of legal protection to fishermen in Bulukumba Regency, South Sulawesi. This article is based on doctrinal law research with a statutory approach and a conceptual approach. The results of this study indicate that the protection of fishermen in Bulukumba district has been carried out using an insurance system since 2016. The insurance premium is borne by the local government which has been budgeted through the Regional Revenue and Expenditure Budget. The obstacle to the implementation of this policy is the legal culture of the people who are reluctant to enroll in programs implemented by the government. In addition, the lack of socialization to the community is also a driving force for weakening public legal awareness of the urgency of selfinsurance when carrying out activities at sea.
\end{abstract}

Keywords: Fishermen, Insurance, legal awareness.

Abstrak:

Nelayan merupakan salah satu pekerjaan yang memiliki resiko tinggi. Perlindungan terhadap pekerjaan ini terkadang nyaris luput dari perhatian pemerintah. Penelitian ini bertujuan untuk mendeksripsikan penerapan perlindungan hukum terhadap nelayan di Kabupaten Bulukumba Sulawesi selatan. Artikel ini berdasarkan Penelitian hukum doctrinal dengan pendekatan perundang-undangan dan pendekatan konsep Hasil penelitian ini menunjukkan bahwa perlindungan nelayan di kabupaten Bulukumba dilakukan menggunakan sistem asuransi sejak tahun 2016. Premi asuransi 
ditanggung oleh pemerintah daerah yang telah dianggarkan melalui Anggaran Pendapatan dan Belanja Daerah. Hambatan pelaksanaan kebijakan ini adalah budaya hukum masyarakat yang enggan mendaftarkan diri dalam program yang dilaksanakan pemerintah. Selain itu, kurangnya sosialisasi kepada masyarakat juga menjadi pendorong melemahnya kesadaran hukum masyarakat terhadap urgensi asuransi diri saat melaksanakan aktifitas di laut.

Kata Kunci: Nelayan, Asuransi, kesadaran hukum.

\section{Pendahuluan}

Indonesia merupakan negara kepulauan ${ }^{1}$ yang berpotensi menjadi poros maritim dunia. ${ }^{2}$ Indonesia memiliki wilayah laut seluas 3,25 juta $\mathrm{km}^{2}$ dan Zona Ekonomi Ekslusif seluas 2,55 juta $\mathrm{km}^{2}{ }^{3}$ Sebagai negara maritim, Indonesia memiliki kawasan pesisir yang cukup luas. Data Kementerian Kelautan dan Perikanan Republik Indonesia menunjukkan bahwa Indonesia memiliki garis pantai sepanjang $95.181 \mathrm{~km} .{ }^{4}$ Kondisi ini menjadikan sebagian penduduk Indonesia bermata pencarian sebagai nelayan. Potensi kemaritiman ini ditindaklanjuti dengan sejumlah kebijakan strategis, salahsatunya peningkatan kesejahteraan dan perlindungan hukum. ${ }^{5}$ Data Kementerian Kelautan dan Perikanan Republik Indonesia menyebut ada 2,7 Juta nelayan di Indonesia. Jumlah ini terus mengalami penurunan karena kurangnya minat masyarakat bekerja pada sektor kelautan. Ironisnya, sebagian besar nelayan mengalami keterbatasan dalam bidang ekonomi dan berada dalam ambang batas garis kemiskinan. ${ }^{6}$

Salah satu daerah yang potensial dalam pengembangan kemaritiman adalah Kabupaten Bulukumba Provinsi Sulawesi Selatan. ${ }^{7}$ Sebagian besar penduduknya bekerja sebagai nelayan. Pada tahun 2007, data Dinas Perikanan dan Kelautan Kabupaten Bulukumba menyebut bahwa jumlah nelayan di kabupaten tersebut adalah 10.128 orang. ${ }^{8}$ Pada tahun 2015 , produksi perikanan tangkap di Kabupaten Bukumba menempati posisi pertama. Hasil produksi perikanan mencapai 53.612 ton dan terus mengalami peningkatan di setiap tahunnya. Sektor perikanan seharusnya

\footnotetext{
${ }^{1}$ P. Joko Subagyo, Hukum Laut Indonesia (Jakarta: Rineka Cipta, 2005), 1.

${ }^{2}$ Kementerian Komunikasi dan Informatika RI, 'Menuju Poros Maritim Dunia', Website Resmi Kementerian Komunikasi dan Informatika RI, accessed 9 October 2020, http:///content/detail/8231/menuju-poros-maritim-dunia/0/kerja_nyata.

${ }^{3}$ Oki Pratama, 'Konservasi Perairan Sebagai Upaya Menjaga Potensi Kelautan Dan Perikanan Indonesia', accessed 9 October 2020, https://kkp.go.id/djprl/artikel/21045-konservasi-perairansebagai-upaya-menjaga-potensi-kelautan-dan-perikanan-indonesia.

${ }^{4}$ Kementerian Kelautan dan Perikanan RI, 'Laut Masa Depan Bangsa, Mari Jaga Bersama', accessed 9 October 2020, https://kkp.go.id/artikel/12993-laut-masa-depan-bangsa-mari-jaga-bersama.

${ }^{5}$ Khanisa Krisman and Lidya C. Sinaga, 'Menakar Keberlanjutan Visi Poros Maritim Dunia Di Tengah Agenda Pembangunan Maritim Regional', Jurnal Penelitian Politik 17, no. 1 (30 June 2020): 106-7, https://doi.org/10.14203/jpp.v17i1.858.

${ }^{6}$ Selfie Miftahul Jannah, 'Pemerintah Targetkan Indonesia Miliki 1 Juta Nelayan Berdaulat', tirto.id, accessed 9 October 2021, https://tirto.id/pemerintah-targetkan-indonesia-miliki-1-juta-nelayanberdaulat-dlwg.

${ }^{7}$ Darmawan Salman, Jagad Maritim (Ininnawa, 2006), 2.

8 Kurnia Arif, 'Analisis Faktor-Faktor yang Mempengaruhi Tingkat Pendapatan Nelayan di Kabupaten Bulukumba' (diploma, Universitas Islam Negeri Alauddin Makassar, 2018), 30, http://repositori.uin-alauddin.ac.id/15365/.
} 
dapat memberikan kontribusi terhadap perekonomian masyarakat. ${ }^{9}$ Namun, kondisi nelayan di Kabupaten Bulukumba masih memiliki problem ekonomi. Riset Kurnia Arif menunjukkan bahwa modal usaha dan modernisasi alat tangkap menjadi sebab tidak stabilnya pendapatan nelayan..$^{10}$ Selain itu, cuaca ekstrim dan kurang akurasi prediksi cuaca menjadikan pendapatan nelayan menjadi tidak pasti. Jika cuaca ekstrim, nelayan memilih tidak melaut dengan pertimbangan keselamatan. ${ }^{11}$

Berbagai resiko yang dihadapi oleh nelayan Indonesia menjadi sebab lahirnya Undang-Undang Nomor 7 tahun 2016 tentang Perlindungan dan Pemberdayaan Nelayan, Pembudidaya Ikan dan Petambak Garam. ${ }^{12}$ Undang-undang ini menjadi dasar Peraturan Menteri Kelautan dan Perikanan Nomor 18/PERMEN-KP/2016 tentang Jaminan Perlindungan Atas Risiko Kepada Nelayan, Pembudidaya Ikan, dan Petambak Garam. Pemerintah melalui kementerian Kelautan Perikanan (KKP) bekerjasama dengan PT Asuransi Jasa Indonesia (Jasindo) memberikan Bantuan Premi Asuransi Nelayan. ${ }^{13}$ Di Kabupaten Bulukumba, asuransi nelayan tahun $2017-$ 2018 diikuti oleh 1.597 orang. Kemudian tahun 2018-2019 mengalami penurunan signifikan yaitu sebanyak 838 nelayan. ${ }^{14}$ Tidak sesuainya premi asuransi serta pengetahuan masyarakat menjadi sebab menurunnya pengguna asuransi nelayan di Kabupaten Bulukumba. Berdasarkan persoalan di atas, artikel ini bertujuan untuk mendeksripsikan penerapan perlindungan hukum terhadap nelayan di Kabupaten Bulukumba Sulawesi selatan. Kemudian menganalisnya menggunakan kesadaran hukum.

\section{Hasil dan Pembahasan \\ Penerapan Asuransi Nelayan Dalam Upaya Melindungi Nelayan Sebagai Bentuk Pengalihan Risiko.}

Kabupaten Bulukumba adalah kabupaten yang mayoritas profesi mata pencarian masyarakatnya adalah sebagai nelayan. Dilihat dari jumlah nelayan ada di Kabupaten Bulukumba yaitu 13.122 orang yang terdiri dari 2.625 nelayan pengusaha dan 10.497 nelayan buruh. ${ }^{15}$ Berdasarkan data tersebut maka perlunya nelayan di Kabupaten Bulukumba mendapatkan perlindungan bagi dirinya dan keluarganya terhadap risiko yang kemungkinan terjadi saat melakukan penangkapan

\footnotetext{
9 Damaiga Hatari Harmunanto, Arifuddin Akil, and Ihsan Ihsan, 'Potensi Perikanan Dalam Peningkatan Perekonomian Studi Kasus Di Kabupaten Bulukumba, Sulawesi Selatan', Seminar Nasional Geomatika 3, no. 0 (15 February 2019): 325-32, https://doi.org/10.24895/SNG.2018.30.972 .

${ }^{10}$ Arif, 'Analisis Faktor-Faktor yang Mempengaruhi Tingkat Pendapatan Nelayan di Kabupaten Bulukumba', 62.

11 'Akibat Cuaca Ekstrim, Nelayan Tidak Melaut', Republika Online, 12 December 2010, https://republika.co.id/berita/breaking-news/nusantara/10/12/12/151734-akibat-cuaca-ekstrimnelayan-tidak-melaut; Amirullah, 'BPBD Sulawesi Tengah Ingatkan Nelayan Waspada Cuaca Ekstrem', Tempo, 11 August 2020, https://nasional.tempo.co/read/1374555/bpbd-sulawesi-tengahingatkan-nelayan-waspada-cuaca-ekstrem.

${ }^{12}$ Teuku Muttaqin Mansur et al., 'Pengaturan Hukum Perlindungan Nelayan Kecil', Kanun Jurnal Ilmu Hukum 19, no. 3 (28 December 2017): 383-97.

${ }^{13}$ Linda Permatasari, Pudjo Suharso, and Wiwin Hartanto, 'Implementasi Program Bantuan Premi Asuransi Nelayan (Bpan) Pada Masyarakat Pesisir Pantai Puger Kabupaten Jember', JURNAL PENDIDIKAN EKONOMI: Jurnal Ilmiah Ilmu Pendidikan, Ilmu Ekonomi Dan Ilmu Sosial 14, no. 1 (1 April 2020): 225-31, https://doi.org/10.19184/jpe.v14i1.12056.

${ }^{14}$ Data Dinas Perikanan Kabupaten Bulukumba Sulawesi Selatan pada tanggal 20 November 2019.

${ }^{15}$ Dinas Perikanan Kabupaten Bulukumba
} 
ikan di laut. Asuransi Nelayan merupakan program pemerintah dalam rangka perlindungan atas risiko terhadap nelayan yang di atur dalam PERMEN KKP Nomor 7 tahun 2016 tentang Perlindungan dan Pemberdayaan Nelayan Pembudidaya Ikan dan Petambak Garam. Pelaksanaan program perlindungan asuransi bagi nelayan diserahkan kepada Dinas Perikanan kabupaten Bulukumba sebagai struktur pelaksana yang bekerja sama dengan perusahaan asuransi jasa Indonesia dalam hal ini perlindungan kecelakaan kerja.

Penangkapan ikan merupakan salah satu aktivitas bagi para nelayan dengan tingkat risiko yang cukup tinggi. ${ }^{16}$ Seperti kecelakaan kerja yang mengakibatkan kematian atau cacat tetap. Berbagai resiko kerja ini dapat mempengaruhi pola kehidupan dan kesejahteraan bagi para nelayan. Masyarakat nelayan di tuntut untuk menafkahi keluarganya dengan bergantung pada hasil sumber daya alam yang berasal dari laut untuk melangsungkan kehidupan dirinya dan keluarganya. Sehingga dalam hal ini nelayan harus di lindungi melalui program asuransi tersebut. Bantuan premi asuransi nelayan (BPAN) merupakan salah satu bentuk perlindungan kepada nelayan demi keberlangsungan kegiatan usaha penangkapan ikan. Adapun tujuan pemberian BPAN untuk memberikan jaminan perlindungan untuk menghindarkan risiko dialami nelayan pada masa yang akan datang, menumbuhkan kesadaran bagi nelayan terhadap pentingnya berasuransi, membangun keinginan nelayan untuk ikut serta berasuransi secara mandiri, memberikan bantuan bagi ahli waris, dan memindahkan risiko yang seharusnya ditanggung nelayan kepada pihak penyedia asuransi. ${ }^{17}$ Adapun sasaran Bantuan Premi Asuransi Nelyan (BPAN) meliputi nelayan kecil dan nelayan tradisional dengan risiko yang dijamin yaitu kematian akibat kecelakaan, cacat tetap akibat kecelakaan, biaya pengobatan akibat kecelakaan dan santunan kematian alami. ${ }^{18}$

Perlindungan hukum terhadap nelayan dalam hal ini memberikan perlindungan terhadap nelayan melalui bantuan premi asuransi nelayan yang dikeluarkan oleh pemerintah berdasarkan Undang-undang Nomor 7 Tahun 2016 tersebut. Menurut Satjipto Rahardjo, bahwa hukum hadir dalam masyarakat untuk mengintegrasikan dan mengkordinasikan kepentingan-kepentingan yang bisa bertubrukan satu sama lain. Pengkoordinasian kepentingan-kepentingan tersebut dilakukan dengan cara membatasi dan melindungi kepentingan-kepentingan terkait. ${ }^{19}$ Sehingga jika dilihat dari sisi perlindungan hukum yang diberikan pemerintah kepada nelayan telah sejalan dengan apa yang di programkan pemerintah dalam hal ini perlindungan terhadap nelayan terhadap risiko yang dihadapi nelayan dalam melakukan pencaharian ikan atau saat melaut. Dinas Perikanan Kabupaten Bulukumba telah melaksanakan program Asuransi Nelayan. Kabupaten Bulukumba yang terdiri dari 9 Kecamatan, 7 diantaranya dipilih dalam menerapkan program asuransi nelayan kerena memiliki pesisir pantai yang di tepati atau didiami oleh nelayan diantaranya adalah Kecamatan Ujungbulu, Kecamatan

\footnotetext{
${ }^{16}$ Lindawati Lindawati and Rikrik Rahadian, 'Identifikasi Faktor Dan Penilaian Risiko Pada Usaha Perikanan Tangkap Di Kabupaten Sambas', Jurnal Sosial Ekonomi Kelautan dan Perikanan 11, no. 1 (30 June 2016): 100, https://doi.org/10.15578/jsekp.v11i1.3175.

${ }^{17}$ Permatasari, Suharso, and Hartanto, 'Implementasi Program Bantuan Premi Asuransi Nelayan (Bpan) Pada Masyarakat Pesisir Pantai Puger Kabupaten Jember'.

18 'Jasindo Dan DKP Mukomuko Sosialisasi Asuransi Nelayan', accessed 11 September 2020, http://infopublik.id/kategori/nusantara/179757/jasindo-dan-dkp-mukomuko-sosialisasi-asuransinelayan?video $=$.

${ }^{19}$ Satjipto Rahardjo, Ilmu Hukum (Bandung: Citra Aditya Bakti, 1991), 53.
} 
Gantarang, Kecamatan Ujungloe, Kecamatan Bontobahari, Kecamatan Bontotiro, Kecamatan Kajang, dan Kecamatan Herlang.

Kementerian Kelautan dan Perikanan menunjuk PT. Asuransi Jasa Indonesia (Jasindo) untuk memberikan jaminan keselamatan kerja bagi nelayan Indonesia. Dalam program bantuan premi asuransi bagi nelayan (BPAN) tersebut diperuntukkan untuk nelayan, dalam Undang-Undang no. 7 tahun 2016 tentang perlindungan dan pemberdayaan nelayan, pembudidaya ikan dan petambak garam, menjelasakan bahwa nelayan yang dimaksud terdiri dari nelayan kecil, nelayan tradisional, nelayan buruh dan nelayan pemilik. Adapun yang menjadi pelaksanaan program asuransi nelayan di Kabupaten Bulukumba yaitu meliputi: Pertama, tahapan sosialisasi. Dalam tahap sosialisasi program asuransi nelayan tercantum dalam Peraturan Direktur Jenderal Perikanan Tangkap Nomor 2 Tahun 2016 Tentang Petunjuk Teknis Bantuan Premi Asuransi Nelayan Pada Direktorat Jenderal Perikanan Tangkap, mengatur tentang bentuk bantuan pemerintah, persyaratan penerima BPAN, mekanisme pencairan bantuan, dan proses tuntutan atau klaim. Tahap sosialisasi yaitu untuk memberikan wawasan kepada nelayan tentang pengertian, manfaat, peruntukan, dan prosedur tahap mengenai Bantuan Premi Asuransi Nelayan (BPAN). Kedua, Pengertian Bantuan premi asuransi nelayan (BPAN). Bantuan premi asuransi nelayan (BPAN) merupakan bantuan pembayaran premi asuransi yang diberikan pemerintah kepada tertanggung (nelayan) dan salah satu bentuk perlindungan kepada nelayan demi keberlangsungan kegiatan usaha penangkapan ikan. Adapun tujuan pemberian BPAN untuk memberikan jaminan perlindungan untuk menghindarkan risiko dialami nelayan pada masa yang akan datang, menumbuhkan kesadaran bagi nelayan terhadap pentingnya berasuransi, membangun keinginan nelayan untuk ikut serta berasuransi secara mandiri, memberian bantuan bagi ahli waris, dan memindahkan risiko yang seharusnya ditanggung nelayan kepada pihak penyedia asuransi. Adapun sasaran BPAN meliputi nelayan kecil dan nelayan tradisional dengan risiko yang dijamin yaitu kematian akibat kecelakaan, cacat tetap akibat kecelakaan, biaya pengobatan akibat kecelakaan dan santunan kematian alami. Ketiga, Manfaat Bantuan Premi Asuransi Nelayan. Rincian manfaat asuransi nelayan sudah diatur dalam Undang-Undang Nomor 18 Tahun 2016 Tentang Jaminan Perlindungan Atas Risiko Kepada Nelayan, Pembudidaya Ikan, dan Petambak Garam. Berikut tabel rincian manfaatnya secara perorangan :

Tabel 1. Data Nilai Manfaat Per Orang Penerima Klaim Asuransi Sesuai Kejadian yang Dialami

\begin{tabular}{|c|c|}
\hline Uraian & Nilai Manfaat Per Orang \\
\hline $\begin{array}{l}\text { a.Resiko Akibat Kecelakaan Pada saat } \\
\text { Penangkapan Ikan. }\end{array}$ & Nelayan melakukan Aktivitas \\
\hline 1. Kematian & Rp. 200.000.000,- \\
\hline 2. Cacat Tetap (Maksimal) & Rp. 100.000.000,- \\
\hline 3. Biaya Pengobatan Maksimal & Rp. 20.000.000,- \\
\hline $\begin{array}{l}\text { b.Resiko Akibat Kecelakaan Pada saat } \\
\text { Selain Penangkapan Ikan. }\end{array}$ & Sedang Melakukan Aktifitas \\
\hline 1. Kematian & Rp. 160.000.000,- \\
\hline
\end{tabular}




\begin{tabular}{ll}
\hline 2. Cacat Tetap Maksimal & Rp. $100.000 .000,-$ \\
\hline 3. Biaya Pengobatan Maksimal & Rp. 20.000.000,- \\
\hline c. Manfaat Pertanggungan Lain Atau & Rp. 5.000.000,- \\
Tambahan Resiko Kematian Selain \\
Akibat Kecelakaan
\end{tabular}

Berdasarkan uraian di atas dapat di lihat bahwa adapun nilai manfaat per orang sesuai apa yang dialami oleh nelayan menetapkan nilai manfaat per orang berupa santunan untuk Resiko akibat Kecelakaan pada saat Penangkapan Ikan sejumlah Rp 200.000.000 apabila menyebabkan kematian, Rp 100.000.000 apabila menyebabkan cacat tetap, dan Rp. 20.000.000 untuk biaya pengobatan. Sementara untuk santunan risiko akibat kecelakaan pada saat selain penangkapan ikan, diberikan manfaat perorangan sejumlah Rp. 160.000 .000 apabila menyebabkan kematian, Rp 100.000.000 untuk yang mengalami cacat tetap, dan biaya pengobatan sebesar Rp. 20.000.000 kemudian Rp. 5.000.000 manfaat Pertanggungan lain atau tambahan risiko kematian selain akibat kecelakaan. Adapun peruntukan asuransi nelayan atau Bantuan Premi Asuransi Nelayan (BPAN) yaitu diperuntukan untuk nelayan kecil dan nelayan tradisional. Adapun ruang lingkup pelaku usaha kelautan dan perikanan tersebut dilihat dalam pasal 3 Permen KKP nomor 39 tahun 2017 menjelaskan yang dimaksud pelaku usaha kelautan dan perikanan adalah: 1) Nelayan yang terdiri dari nelayan kecil nelayan tradisional nelayan buruh dan nelayan pemilik. 2) Pembudidaya ikan yang terdiri dari pembudidaya ikan kecil penggarap lahan dan pemilik lahan. 3) Petambak garam yakni petambak kecil penggarap tambak dan pemilik tambak. 4) Pengelolaan dan pemasaran ikan. 5) Penyedia jasa pengiriman produk kelautan dan perikanan.

Dalam tahap sosialisasi, dijelaskan persyaratan untuk menerima Bantuan Premi Asuransi Nelayan (BPAN), yaitu :20 1) Terdaftar dalam modul KUSUKA (Perseorangan) pada laman satudata.kkp.go.id; 2) Berusia maksimal 65 tahun pada tanggal 31 Desember 2019; 3) Menggunakan kapal penangkap ikan berukuran paling besar 10 (sepuluh) Gross Tonnage (GT); 4) Tidak menggunakan alat penangkap ikan terlarang berdasarkan ketentuan peraturan perundang undangan; 5) Diutamakan bagi yang tidak pernah mendapatkan program Asuransi dari kementerian, pemerintah provinsi, pemerintah kabupaten/kota, atau pernah mendapatkan program asuransi dari kementerian, pemerintah provinsi, pemerintah kabupaten/kota, namun polis asuransinya telah berakhir masa berlakunya atau jenis risiko yang diamin berbeda; 6) Mematuhi ketentuan sebagaimana tercantum dalam polis asuransi.

Persyaratan dalam bantuan premi asuransi nelayan yang telah diuruikan di atas terdaftar dalam modul kusuka dimana hal tersebut nelayan harus memiliki Kartu Pelaku Usaha Kelautan Dan Perikanan (Kusuka). Kartu tersebut merupakan pengganti dari kartu nelayan dan memiliki banyak manfaat, salah satunya untuk proses perpanjangan asuransi. Adapun yang berhak memiliki Kartu Pelaku Usaha Kelautan Dan Perikanan (Kusuka) adalah nelayan, pembudidaya ikan, petambak garam, pemasaran ikan serta pengusaha jasa pengiriman hasil perikanan. setelah terdaftar dan terdata di laman satudata.kkp.go.id yang di input oleh dinas perikanan

\footnotetext{
${ }^{20}$ Peraturan Direktur Jenderal Perkanan Tangkap Nomor 2/PER-DPT/2019 tentang Petunjuk Teknis Bantuan Premi Asuransi Nelayan Pada Direktorat Jenderal Perikanan Tangkap.
} 
setempat, berdasarkan umur dimana nelayan yang telah berusia diatas 65 tahun maka tidak dapat mendaftar dalam program asuransi nelayan tersebut, berdasarkan syarat menggunakan kapal penangkap ikan berukuran paling besar 10 (sepuluh) Gross Tonnage (GT) jadi nelayan yang memiliki kapal yang melebihi 10 GT maka tidak dapat mengikuti program asuransi nelayan juga karena pemerintah telah mensyaratkan kapasitas maksimum muatan kapal nelayan selain itu pemerintah juga menganggap bahwa kapal yang memilii kapasitas di bawah 10 Gross Tonnage (GT) dianggap sebagai nelayan kecil dan nelayan tradisional. Kemudian tidak menggunakan alat penangkap ikan terlarang berdasarkan ketentuan peraturan perundang undangan yaitu dapat dilihat dalam peraturan menteri kelautan dan perikanan nomor 71 tahun 2016 Bab III alat penangkap ikan pasal 6 menjelaskan alat penangkapan ikan menurut jenisnya terdiri dari 10 sepuluh kelompok yaitu jaring lingkar, pukat tarik, pukat hela, penggaruk, jaring angkat, alat yang dijatuhkan, jaring insang, perangkap pancing, alat penjepit, dan melukai. Adapun dalam proses tuntutan/klaim yaitu dapat dilihat dari skema berikut, yaitu :

Gambar 1. Proses Tuntutan/Klaim

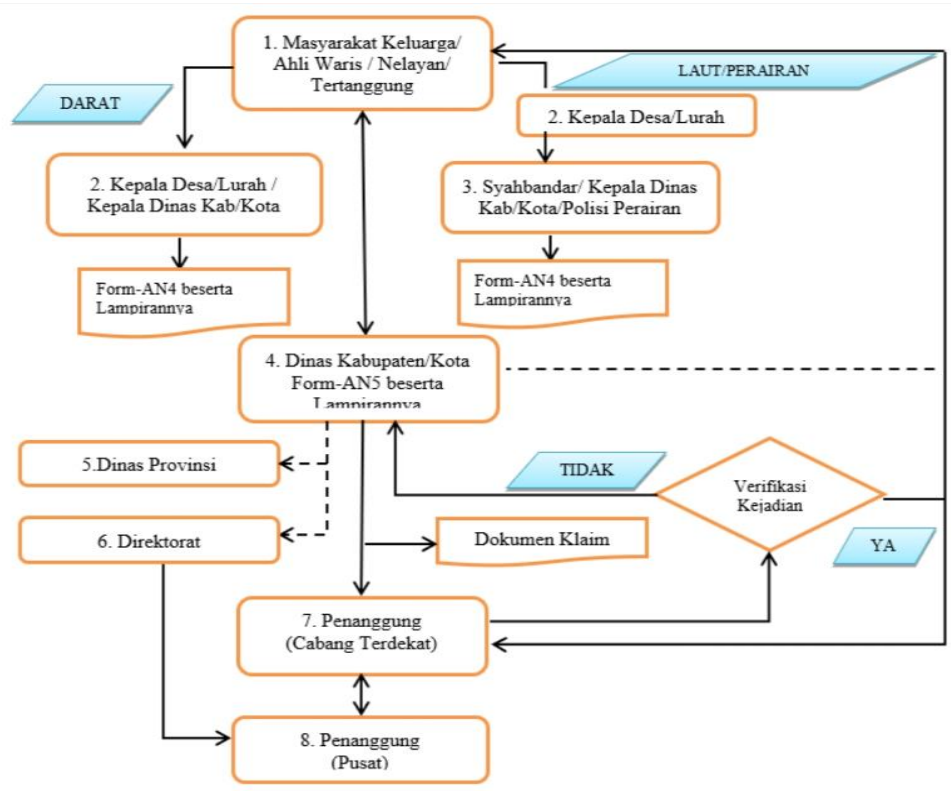

Dalam proses tuntutan/klaim di atas dapat diuraikan sebagai berikut: a) Pengajuan tuntutan/klaim dari tertanggung melalui Dinas kabupaten /kota kepada penanggung diajukan paling lambat 30 hari sejak tanggal kejadian; b) Dalam hal tertanggung mengalami kematian alami, klaim hanya dapat diajukan kepada penanggung stelah masa tunggu selama 1 (satu) bulan sejak polis realisasi diterbitkan; c) Keluarga, ahli waris, atau tertanggung melengkapi dokumen klaim (umum dan khusus); d) Penanggung melakukan verifikasi klaim paling lambat 6 (enam) hari sejak dokumen klaim lengkap; e) Penanggung menerbitkan berita acara keputusan klaim (BAKK) paling lambat enam hari kerja setelah pelaksanaan verifikasi; f) Jika dalam waktu 14 hari kerja sejak pemberitahuan kejadian kecelakaan diterima oleh penanggung dari kepala Dinas kabupaten/kota belum terbit BAKK, maka penanggung dinyatakan setuju terhadap klaim yang diajukan oleh tertanggung/ahli waris; g) Manfaat klaim wajib dibayarkan paling lambat 7 (tujuh) hari kerja ke 
rekening tertanggung/ahli waris setelah tanggal penandatangannan BAKK. Adapun alur dalam pembuatan Kartu Pelaku Usaha Bidang Kelautan dan Perikanan (Kusuka) dapat di lihat dari alur SOP yaitu:

Gambar 2. Bagan alur pembuatan Kartu Kusuka dalam SOP

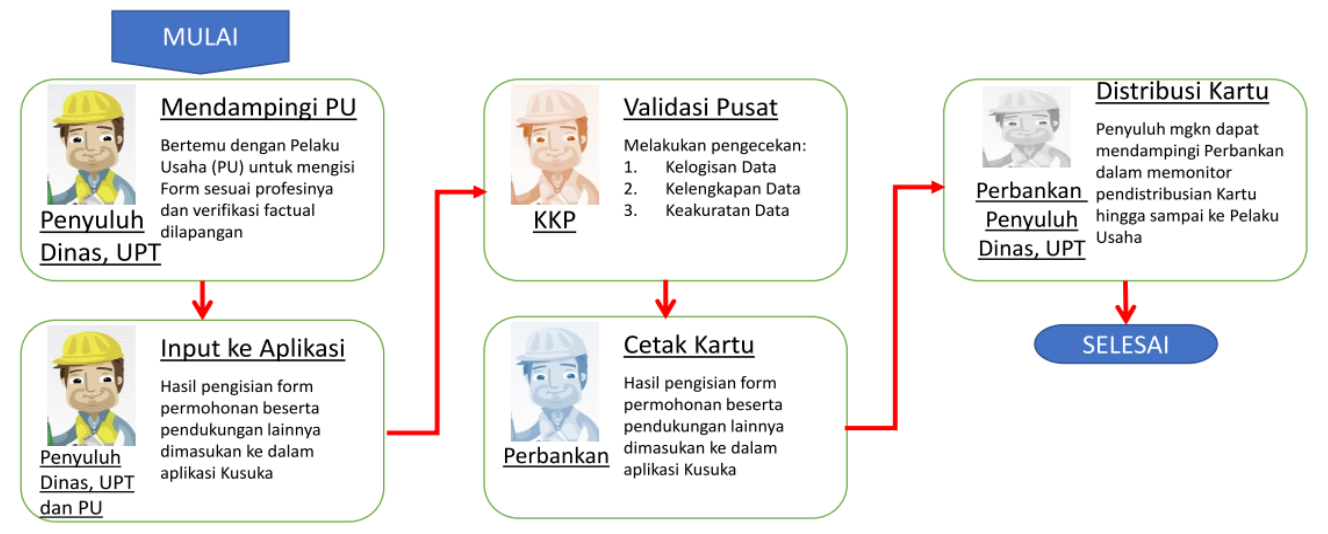

Sumber: Peraturan Direktur Jenderal Perikanan Tangkap Nomor 1 tahun 2019 tentang petunjuk teknis bantuan premi asuransi bagi nelayan tahun 2019 .

Tata cara mendapatkan atau mendaftar Kartu Kusuka yaitu: a) Secara online. Mendaftar pada situs https: //satudata.kkp.go.id/ dan menunggu proses administrasi dari administrator; b) Secara langsung. Dengan datang langsung ke Dinas kelautan dan perikanan kabupaten/ kota atau UPT dilokasi terdekat, kemudian mengisi formulir permohonan penerbitan kartu kusuka. Menyiapkan fotokopi ktp orang perseorangan atau penanggung jawab korporasi. Melampirkan surat keterangan dari kepala desa lurah yang menyatakan bahwa yang bersangkutan bekerja sebagai pelaku usaha kelautan dan perikanan untuk perseorangan. Fotokopi nomor pokok wajib pajak (NPWP) untuk korporasi. Masa berlaku kartu kusuka selama lima tahun dan dapat diperpanjang dan pergantian kartu kusuka tidak dikenakan biaya.

Dalam pelaksanaan program asuransi nelayan, Dinas Perikanan Kabupaten Bulukumba, Melakukan pendataan dengan jumlah anggota 14 orang yang tersebar di berbagai wilayah pesisir di bulukumba yang telah terdata sebagai wilayah yang menerima bantuan premi asuransi nelayan. Tahap pendataan tersebut Dinas Perikanan Kabupaten Bulukumba melakukan sistem pendataan yang terdiri dari tenaga pendampig. Tenaga pendamping terdiri dari 2 orang di setiap kecamatan. Kemudian Sosialisasi diselenggarakan dengan mengundang perwakilan nelayan rata-rata 30 orang setiap kecamatan. Pelaksanaan program asuransi nelayan adapun yang berperan dalam tata kelola tersebut yaitu Direktorat, Pusdatin (pusat data dan informasi), Puslatluh (pusat latihan dan penyuluh)/UPT BRSDM KP/penyuluhan perikanan, dinas provinsi, dinas kabupaten/kota, dan penanggung. Program asuransi nelayan di Bulukumba dimulai pada tahun 2016 dan telah berlangsung selama 4 tahun. Dapat dilihat dalam tabel berikut:

Tabel 2. Data Penerima Klaim Asuransi di Kabupaten Bulukumba 


\begin{tabular}{|c|c|c|c|c|c|}
\hline No & $\begin{array}{c}\text { Tahun } \\
\text { Penerapan }\end{array}$ & $\begin{array}{l}\text { Nelayan yang } \\
\text { Mengikuti } \\
\text { Asuransi }\end{array}$ & $\begin{array}{l}\text { Jumlah } \\
\text { Premi }\end{array}$ & $\begin{array}{l}\text { Jumlah } \\
\text { Klaim }\end{array}$ & Jenis Klaim \\
\hline 1. & 2016 & 496 & $\begin{array}{c}\text { Rp. } \\
170.000\end{array}$ & - & - \\
\hline 2. & 2017 & 1.597 & $\begin{array}{c}\text { Rp. } \\
170.000\end{array}$ & 2 & $\begin{array}{l}\text { Biaya } \\
\text { pengobatan dan } \\
\text { Kematian Alami }\end{array}$ \\
\hline 3 & 2018 & 838 & $\underset{170.000}{\text { Rp. }}$ & 3 & Kematian Alami \\
\hline 4 & 2019 & 867 & $\begin{array}{c}\text { Rp. } \\
140.000\end{array}$ & 4 & $\begin{array}{l}\text { Pengobatan dan } \\
\text { Kematian Alami }\end{array}$ \\
\hline
\end{tabular}

Pada tahun pertama, penerapan asuransi nelayan belum di minati oleh nelayan, sebab masih tahap sosialisasi dan belum terjadi klaim. Tahap sosialisasi tersebut di lakukan oleh Dinas Perikanan kabupaten bulukumba, Dinas Keluatan dan Perikanan Provinsi Sulawesi Selatan dan Jasa Asuransi Indonesia (Jasindo). Menurut Taufik ${ }^{21}$, Staf bidang Perikanan Kabupaten Bulukumba yang menangani tentang program Asuransi Nelayan. Dalam penerapan asuransi nelayan di tahun pertama merupakan tahap sosialisasi dan belum terjadi klaim sebab masyarakat tidak mengerti atau belum terlalu memahami tentang prosedur asuransi jadi seharusnya yang mendapat klaim kematian justru klaimnya tidak bisa di proses karena terlambat melapor ke dinas sehingga klaimnya gugur dengan sendirinya. Ditahun kedua, Asuransi nelayan telah berjalan dan telah terdata 1.597 nelayan ditahun 2017 hal tersebut mengalami peningkatan dari sebelumnya 496 nelayan di tahun pertama atau tahun 2016, adapun bantuan premi asuransi nelayan di berikan kepada nelayan yaitu Rp.170.000 tiap nelayan, dan pada tahun yang sama juga telah terjadi klaim sebanyak 2 orang yaitu dari biaya pengobatan akibat kecelakaan hingga kematian. Melihat dari data minat masyarakat atau nelayan tersebut asuransi nelayan semakin meningkat. Dalam proses memperoleh klaim nelayan harus memiliki kartu nelayan berdasarkan syarat dalam dalam penerimaan bantuan premi asuransi nelayan kemudian terdata dalam Dinas Perikanan Kabupaten Bulukumba.

Dalam pelaksanaan program asuransi nelayan berdasarkan peraturan Direktur Jenderal Perikanan Tangkap Nomor 1 tahun 2017 tentang petujuk teknis bantuan premi asuransi nelayan bagi nelayan ditahun 2017, petunujuk teknis bantuan premi asuransi bagi nelayan tahun 2017 merupakan acuan bagi Direktorat Jenderal Perikanan Tangkap dan Pemerintah daerah dalam rangka pelaksanaan bantuan premi asuransi bagi nelayan tahun 2017. Pada tahun ketiga, yaitu pada tahun 2018 nelayan di bulukumba mendapatkan bantuan premi asuransi nelayan Rp. 170.000 tiap nelayan, ditahun ini juga yang mengikuti asuransi nelayan mengalami

\footnotetext{
${ }^{21}$ Wawancara dengan Staf bidang Perikanan dalam Penanganan Program Asuransi Nelayan, Dinas Perikanan Kabupaten Bulukumba, Taufik, S.E, Pada tanggal 05 Februari.
} 
penurunan, melihat sebelumnnya di tahun 2017 sebanyak 1.597 yang mengikuti program asuransi nelayan dan pada tahun 2018 terdata hanya 838 nelayan yang mengikuti program asuransi tersebut, sehingga melihat angka perbedaan dari tahun 2017 ke 2018 mengalami penurunan hampir di angka 50\% dan yang mengajuan klaim sebanyak 3 orang yang telah terbayarkan dan disebabkan akibat kematian alami. Berdasarkan data yang diambil dari dinas perikanan kabupaten bulukumba dan hasil wawancara yang dilakukan penulis, asuransi nelayan mengalami penurunan sebab banyaknya masyarakat atau nelayan yang enggan mengurus kartu kusuka disisi lain juga karena sistem administrasi yang melambat karena kartu kusuka tersebut di buat diterbitkan di kantor bank BNI. Kartu kusuka (Kartu pelaku Usaha kelautan dan Perikanan) tersebut berganti dari sebelumnya kartu nelayan diganti menadi kartu kusuka berdasarkan peraturan menteri KKP nomor 39 tahun 2017 tentang kartu pelaku usaha kelautan dan perikanan kartu kusuka ditunjukan untuk perlindungan dan pemberdayaan pelaku usaha kelautan dan perikanan, percepatan pelayanan, peningkatan kesejahteraan serta menciptakan efektivitas dan efisiensi program kementerian kelautan dan perikanan. Dalam pelaksanaan program asuransi nelayan dilaksanakan berdasarkan peraturan Direktur Jenderal Perikanan Tangkap Nomor 1 tahun 2018 tentang petujuk teknis bantuan premi asuransi nelayan bagi nelayan ditahun 2018.

Menurut Taufik S.E selaku staff bidang perikanan tangkap yang menangani asnel tersebut, mengatakan kartu kusuka hadir atau diterapkan dikabupaten bulukumba dimulai di tahun 2018 ini, sehingga masyarakat yang sebelumnya menggunakan kartu nelayan diganti menjadi kartu kusuka atau kartu pelaku usaha kelautan dan perikanan, dalam proses pergantian kartu tersebut dinas perikanan bertugas dalam hal ini tahap pengimputan data nelayan kemudian setelah tahap pengimputan selesai maka selanjutnya kartu kusuka ini dikeluarkan oleh bank BNI. Ditahun keempat dalam pelaksanaan program asuransi nelayan dilaksanakan berdasarkan peraturan Direktur Jenderal Perikanan Tangkap Nomor 1 tahun 2019 tentang petujuk teknis bantuan premi asuransi nelayan bagi nelayan ditahun 2019. Pada tahun 2019, nelayan yang mengikuti program asuransi berdasarkan data dari dinas perikanan kabupaten bulukumba terdata di tahun 2019 sebanyak 867 nelayan, hal tersebut mengalami kenaikan tetapi tidak cukup signifikan karena penambahannya hanya sebanyak 29 nelayan yang mengalami peningkatan dari sebelumnya 838, adapun bantuan premi Rp.140.000 tiap nelayan, klaim yang terjadi di tahun ini ada 4 nelayan adapun jenis klaimnya, yaitu pengobatan/kecelakaan kerja 2 nelayan dan kematian alami 2 nelayan.

Berdasarkan nilai manfaat per orang sesuai apa yang dialami oleh nelayan menetapkan nilai manfaat per orang berupa santunan untuk Resiko akibat Kecelakaan pada saat Penangkapan Ikan sejumlah $\mathrm{Rp} 200.000 .000$ apabila menyebabkan kematian, Rp 100.000.000 apabila menyebabkan cacat tetap dan Rp. 20.000.000 untuk biaya pengobatan. Sementara untuk santunan risiko akibat kecelakaan pada saat selain penangkapan ikan, diberikan manfaat perorangan sejumlah Rp. 160.000.000 apabila menyebabkan kematian, Rp 100.000.000 untuk yang mengalami cacat tetap, dan biaya pengobatan sebesar Rp. 20.000.000 kemudian Rp. 5.000.000 manfaat Pertanggungan lain atau tambahan risiko kematian selain akibat kecelakaan. Berdasarkan data yang di dapatkan penulis bahwa jumlah pertanggungan tidak sesuai dengan jumlah klaim yang diperoleh nelayan yang 
mengikuti program asuransi di Kabupaten Bulukumba. Adapun lebih rinci dapat dilihat sebagai berikut :

Tabel 3. Data Jumlah klaim Asuransi Nelayan Tahun 2017-2019

\begin{tabular}{|c|c|c|c|c|c|}
\hline No & $\begin{array}{l}\text { Nama } \\
\text { Nelayan }\end{array}$ & Alamat & Jenis klaim & $\begin{array}{c}\text { Tanggal } \\
\text { BAK }\end{array}$ & $\begin{array}{l}\text { Jumlah } \\
\text { (Rp) }\end{array}$ \\
\hline 1 & Sirajuddin & Bintarore & $\begin{array}{l}\text { Biaya } \\
\text { pengobatan } \\
\text { (kecelakaan } \\
\text { motor) }\end{array}$ & $16-06-2017$ & 6.153 .350 \\
\hline 2 & Harfin & Bintarore & Kematian Alami & 29-09-2017 & $\begin{array}{l}160.000 .00 \\
0\end{array}$ \\
\hline 3 & Ambo Masse & Babana & Kematian Alami & $27-02-2018$ & 40.000 .000 \\
\hline 4 & $\begin{array}{l}\text { Syamsuddin } \\
\text { C }\end{array}$ & Bentenge & Kematian Alami & 2018 & 20.000 .000 \\
\hline 5 & Muh. Ishak & $\begin{array}{l}\text { Tanah } \\
\text { Jaya }\end{array}$ & Kematian Alami & 2018 & $\begin{array}{l}160.000 .00 \\
0\end{array}$ \\
\hline 6 & Syamruddin & Ekatiro & $\begin{array}{l}\text { Pengobatan } \\
\text { kecelakaan kerja }\end{array}$ & $\begin{array}{l}\text { Nopember } \\
19\end{array}$ & 11.693 .000 \\
\hline 7 & Kamran & Bira & Kematian Alami & & 5.000 .000 \\
\hline 8 & Muh. Nawir & Sapolohe & Kematian Alami & & 5.000 .000 \\
\hline 9 & Lukman & Sapolohe & $\begin{array}{l}\text { Pengobatan } \\
\text { kecelakaan kerja }\end{array}$ & & 6.280 .200 \\
\hline
\end{tabular}

Sumber : Dinas Perikanan Kabupaten Bulukumba 2020.

Dalam data diatas menunjukkan bahwa ketetapan nilai manfaat per orang penerima klaim asuransi sesuai kejadian yang dialami tidak sesuai antara nilai manfaat per orang penerima klaim asuransi sesuai kejadian yang dialami dengan data capaian asuransi nelayan jumlah klaim tahun 2017-2019. Hal tersebut menunjukkan dimana dimulai ditahun 2017 hingga 2019 mengalami jumlah penurunan pembayaran terhadap klaim yang harusnya di terima oleh nelayan yang telah mengalami risiko kecelakaan hingga kematian. Menurut Fatma Sudarma selaku Staff Bidang Perikanan Tangkap Dinas kelautan dan Perikanan Provinsi Sulsel yang menangani tentang program asuransi nelayan yaitu menjelaskan bahwa setiap tahun terjadi perubahan nilai manfaat per orang penerima klaim asuransi kejadian yang dialami nelayan seperti pada tahun 2019 terjadi perubahan dimana pada tahun 2019 jika nelayan mengalami kematian atau meninggal alami maka nelayan tersebut hanya mendapat 5.000.000 dimana hal tersebut berbeda ditahun sebelumnya sehingga hal tersebut terjadi perbedaan pertanggungan yang di bayarkan atau diberikan kepada nelayan. ${ }^{22}$

Adapun yang menjadi perubahan dari jumlah pertanggungan yaitu sesuai dengan juknis/panduan teknis dalam hal pelaksanaan kegiatan program asuransi nelayan yang dikeluarkan oleh kementerian kelautan dan perikanan dapat dilihat

\footnotetext{
${ }^{22}$ Wawancara dengan Staff Bidang perikanan tangkap Dinas kelautan dan Perikanan Provinsi Sulsel yang menangani tentang program asuransi nelayan, Irma Sudarma, Pada tanggal 9 Maret 2020.
} 
dalam peraturan direktur jenderal kelautan dan perikanan tangkap nomor 2 tahun 2019 tentang petunjuk teknis bantuan premi asuransi nelayan pada direktorat jenderal perikanan tangkap. Regulasi tersebut mengalami perubahan ditiap tahunnya yang dikeluarkan oleh kementerian kelautan dan perikanan. ${ }^{23}$ Berdasarkan uraian diatas kita dapat melihat bahwa adapun yang menjadi tidak terpenuhinya atau ketidaksesuaian dalam pembayaran pertanggungan hal tersebut di karenakan adanya perubahan terhadap nilai manfaat penerima klaim pertiap tahunnya yang ditetapkan oleh pemerintah berdasarkan anggaran yang diberikan kepada nelayan. Kemudian jika dilihat dalam peraturan direktur jenderal perikanan tangkap nomor 2 tahun 2019 berdasarkan tujuan dari diadakannya program asuransi nelayan dalam hal ini bantuan premi asuransi nelayan, yaitu: memberikan jaminan perlindungan untuk menghindarkan risiko yang dialami nelayan pada masa yang akan datang, menumbuhkan kesadaran bagi nelayan terhadap pentingnya berasuransi, membangun keinginan nelayan untuk ikut serta berasuransi secara mandiri, memberikan bantuan bagi ahli waris dan memindahkan risiko yang seharusnya ditanggung nelayan kepada pihak penytedia asuransi

Jika melihat dari tujuan bantuan premi asuransi nelayan diadakan maka tujuan dari BPAN tersebut belum sepenuhnya tercapai, karena nelayan dibulukumba dalam hal menumbuhkan kesadaran bagi nelayan terhadap pentingnya berasuransi sebagiannya belum terlaksana, hal tersebut dapat dilihat dari hasil penelitan yang dilakukan penulis yaitu pertumbuhan masyarakat nelayan di kabupaten bulukumba yang mayoritas berprofesi bermata pencarian masyarakatnya adalah sebagai nelayan, dilihat dari jumlah nelayan ada di kabupaten bulukumba yaitu 13.122 orang yang terdiri dari 2.625 nelayan pengusaha dan 10.497 nelayan buruh, dan pebandingan antara mengikuti program asuransi di tiap tahunya hanya berkisar ratusan nelayan, yaitu dimana ditahun terakhir tahun 2019 dapat kita lihat yang mengkuti program asuransi nelayan hanya sebanyak 838 nelayan, maka dengan angka tersebut kita dapat melihat dari tujuan program tersebut belum mencapai 50 $\%$. Selain hal tersebut kita juga dapat melihat dari tujuan lainnya yaitu membangun keinginan nelayan untuk ikut serta berasuransi secara mandiri juga belum tercapai karena dilihat dari pembayaran premi terkait asuransi nelayan di bulukumba yaitu masih ditanggung oleh pemerintah dan belum bersifat mandiri, sehingga tujuan dari BPAN tersebut belum terlaksana di kabupaten bulukumba.

Berdasarkan uraian di atas jika dikaitkan dalam teori efektifitas hokum maka hal tersebut belum efektif dilihat dari definisi efektifitas yaitu, bahwa suatu hal dapat dikatakan efektif apabila hal tersebut sesuai dengan yang dikehendaki. Artinya, pencapaian hal yang dimaksud merupakan pencapaian tujuan dilakukannya tindakan-tindakan untuk mencapai hal tersebut. Efektivitas dapat diartikan sebagai suatu proses pencapaian suatu tujuan yang telah ditetapkan sebelumnya. Kemudian melihat dari pendapat Achmad Ali bahwa ketika kita ingin mengetahui sejauh mana efektivitas dari hukum, maka kita pertama-tama harus dapat mengukur "sejauh mana aturan hukum itu ditaati atau tidak ditaati". Lebih lanjut Achmad Alipun mengemukakan bahwa pada umumnya faktor yang banyak mempengaruhi efektivitas suatu perundang-undangan adalah profesional dan optimal pelaksanaan peran, wewenang dan fungsi dari para penegak hukum, baik di dalam menjalankan

\footnotetext{
23 Wawancara dengan Staff Jasindo dalam penanganan program asuransi nelayan dan asuransi pertanian kantor cabang Jasindo, kota Makassar, Aswir, Pada tanggal 22 April 2020.
} 
tugas yang dibebankan terhadap diri mereka maupun dalam menegakkan perundang-undangan tersebut. Dengan pendapat tersebut dapat kita lihat bahwa selain dari masyarakat itu sendiri yang menyebabkan suatu tujuan itu tidak berjalan maka penyebab lainnya tidak terlaksananya tujuan BPAN tersebut yaitu dari penegakkan hokum atau yang menjalakankan peran dalam pelaksanaan program tersebut.

\section{Kesimpulan}

Berdasarkan uraian di atas dapat disimpulkan bahwa negara bertanggungjawab dalam melakukan perlindungan kepada warga negara. Perlindungan ini diberikan bagi mereka yang melakukan pekerjaan-pekerjaan rawan bahaya. Perlindungan nelayan di kabupaten Bulukumba dilakukan menggunakan sistem asuransi sejak tahun 2016. Premi asuransi ditanggung oleh pemerintah daerah yang telah dianggarkan melalui Anggaran Pendapatan dan Belanja Daerah. Hambatan pelaksanaan kebijakan ini adalah budaya hukum masyarakat yang enggan mendaftarkan diri dalam program yang dilaksanakan pemerintah. Selain itu, kurangnya sosialisasi kepada masyarakat juga menjadi pendorong melemahnya kesadaran hukum masyarakat terhadap urgensi asuransi diri saat melaksanakan aktifitas di laut.

\section{Daftar Pustaka}

Republika Online. 'Akibat Cuaca Ekstrim, Nelayan Tidak Melaut', 12 December 2010. https://republika.co.id/berita/breakingnews/nusantara/10/12/12/151734-akibat-cuaca-ekstrim-nelayan-tidakmelaut.

Amirullah. 'BPBD Sulawesi Tengah Ingatkan Nelayan Waspada Cuaca Ekstrem'. Tempo, 11 August 2020. https://nasional.tempo.co/read/1374555/bpbdsulawesi-tengah-ingatkan-nelayan-waspada-cuaca-ekstrem.

Arif, Kurnia. 'Analisis Faktor-Faktor yang Mempengaruhi Tingkat Pendapatan Nelayan di Kabupaten Bulukumba'. Diploma, Universitas Islam Negeri Alauddin Makassar, 2018. http://repositori.uin-alauddin.ac.id/15365/.

Harmunanto, Damaiga Hatari, Arifuddin Akil, and Ihsan Ihsan. 'Potensi Perikanan Dalam Peningkatan Perekonomian Studi Kasus Di Kabupaten Bulukumba, Sulawesi Selatan'. Seminar Nasional Geomatika 3, no. 0 (15 February 2019): 325-32. https://doi.org/10.24895/SNG.2018.3-0.972.

Jannah, Selfie Miftahul. 'Pemerintah Targetkan Indonesia Miliki 1 Juta Nelayan Berdaulat'. tirto.id. Accessed 9 October 2021. https://tirto.id/pemerintahtargetkan-indonesia-miliki-1-juta-nelayan-berdaulat-dlwg.

'Jasindo Dan DKP Mukomuko Sosialisasi Asuransi Nelayan'. Accessed 11 September 2020. http://infopublik.id/kategori/nusantara/179757/jasindodan-dkp-mukomuko-sosialisasi-asuransi-nelayan?video $=$.

Kementerian Kelautan dan Perikanan RI. 'Laut Masa Depan Bangsa, Mari Jaga Bersama'. Accessed 9 October 2020. https://kkp.go.id/artikel/12993-lautmasa-depan-bangsa-mari-jaga-bersama.

Kementerian Komunikasi dan Informatika RI. 'Menuju Poros Maritim Dunia'. Website Resmi Kementerian Komunikasi dan Informatika RI. Accessed 9 
October 2020. http:///content/detail/8231/menuju-poros-maritimdunia/0/kerja_nyata.

Krisman, Khanisa, and Lidya C. Sinaga. 'Menakar Keberlanjutan Visi Poros Maritim Dunia Di Tengah Agenda Pembangunan Maritim Regional'. Jurnal Penelitian Politik 17, no. 1 (30 June 2020): 103-16. https://doi.org/10.14203/jpp.v17i1.858.

Lindawati, Lindawati, and Rikrik Rahadian. 'Identifikasi Faktor Dan Penilaian Risiko Pada Usaha Perikanan Tangkap Di Kabupaten Sambas'. Jurnal Sosial Ekonomi Kelautan dan Perikanan 11, no. 1 (30 June 2016): 99-107. https://doi.org/10.15578/jsekp.v11i1.3175.

Mansur, Teuku Muttaqin, Muazzin Muazzin, Teuku Ahmad Yani, and Sulaiman Sulaiman. 'Pengaturan Hukum Perlindungan Nelayan Kecil'. Kanun Jurnal Ilmu Hukum 19, no. 3 (28 December 2017): 383-97.

Permatasari, Linda, Pudjo Suharso, and Wiwin Hartanto. 'Implementasi Program Bantuan Premi Asuransi Nelayan (Bpan) Pada Masyarakat Pesisir Pantai Puger Kabupaten Jember'. JURNAL PENDIDIKAN EKONOMI: Jurnal Ilmiah Ilmu Pendidikan, Ilmu Ekonomi Dan Ilmu Sosial 14, no. 1 (1 April 2020): 22531. https://doi.org/10.19184/jpe.v14i1.12056.

Pratama, Oki. 'Konservasi Perairan Sebagai Upaya Menjaga Potensi Kelautan Dan Perikanan Indonesia'. Accessed 9 October 2020. https://kkp.go.id/djprl/artikel/21045-konservasi-perairan-sebagai-upayamenjaga-potensi-kelautan-dan-perikanan-indonesia.

Rahardjo, Satjipto. Ilmu Hukum. Bandung: Citra Aditya Bakti, 1991.

Salman, Darmawan. Jagad Maritim. Ininnawa, 2006.

Subagyo, P. Joko. Hukum Laut Indonesia. Jakarta: Rineka Cipta, 2005. 